\title{
26 \\ Refugee Policy: A Cruel Bipartisanship
}

\section{Sara Dehm and Max Walden}

Facing the media after a reported 5.6 per cent swing against him in the Brisbane seat of Dickson, Australian Minister for Immigration and Border Protection Peter Dutton defiantly declared that the Coalition was 'a victim of our own success'. 'The fact that we stopped boats and got children out of detention', Dutton asserted, meant the 'issue' of 'border protection' and people arriving in Australia unauthorised by boat to seek asylum 'had gone off the radar' (quoted in Hutchens 2016). The minister's assertion was certainly provocative, if a little misleading. While Australia's policies towards refugees and asylum seekers did not appear to feature prominently in the 2016 election campaign, this was largely due to a confluence of circumstances, not all of which were of the Coalition's making. These circumstances primarily included the bipartisan support for the three key pillars of Australia's increasingly draconian deterrence model (namely, boat turn backs, regional processing and the mandatory detention of certain asylum seekers) and the exceptional government censorship of information from inside immigration detention centres and the official secrecy surrounding the implementation of Australia's military-led Operation Sovereign Borders (OSB). This meant that the Coalition and Labor had both orchestrated a situation where there seemed

1 At the time that Dutton faced the media, a 5.6 per cent swing was reported. The final result was a 5.12 per cent swing away from the minister. 
to be little political mileage to be gained from foregrounding the issue of Australia's refugee laws and policies during the campaign. Instead, the election contest predominantly played out across more traditional issues of economic and social policy, such as job creation and the funding of healthcare. Despite being a highly volatile political issue, refugee policy could rarely be seen to determine the outcome of elections-perhaps with the exception of the Coalition's major 2001 electoral victory in the wake of the Tampa affair. Since 2004, fewer than 10 per cent of surveyed voters have ranked the issue of 'refugees and asylum seekers' as the 'most important non-economic issue' in federal elections (McAllister and Cameron 2014: 21).

Despite the lack of prominence given by the two major political parties to the issue of refugee policy relative to previous election campaigns, it nonetheless surfaced at key moments to reveal its political potency. For example, some minor political parties, certain media outlets and community activist groups were particularly vocal on the issue. This chapter argues that these moments attest to both the anxious nature of Australian nationalism and multiculturalism, and the increasingly prominent deep discursive linkages between asylum seekers, terrorism and the securitisation of migration and borders.

\section{International and domestic context}

In the lead-up to the 2016 election, political conditions appeared ripe for the issue of Australia's refugee laws and policies to feature prominently in the federal election campaign. Globally, the number of refugees, asylum seekers and forcibly displaced people had reached a peak of 65.3 million in early 2016, amounting to a humanitarian crisis on a scale not seen since the aftermath of World War II (United Nations High Commissioner for Refugees (UNHCR) 2016). Domestically, Australia's laws and policies towards refugees and asylum seekers—specifically those people who are categorised under Australian law as 'unauthorised maritime arrivals'-have featured as a divisive but not necessarily determinative issue in almost every federal Australian election since the 1970s. In this section, we posit that four important factors shaped the appearance of the issue of Australia's refugee policies in the lead-up to the 2016 federal election. These are (1) the rise of a politics of border security as a frame for understanding the unauthorised arrival of asylum seekers by boat in 
Australia's waters and the reintroduction of regional detention and offshore processing arrangements since 2012; (2) the deteriorating conditions for people held in Australian-run onshore and offshore immigration detention centres; (3) the heightened domestic and international scrutiny of Australia's detention regime including through legal challenges; and (4) a revitalisation of transnational activism to challenge Australia's refugee deterrence paradigm since early 2016. While the latter three factors would appear to give momentum to an increased visibility of the issue of refugee policies in the lead-up to the 2016 election, ultimately the nature and dominance of the first factor proved to be the most decisive. We thus argue that the uneasy bipartisanship between the Coalition and the Australian Labor Party (ALP) around the adoption of an increasingly punitive deterrence model towards people travelling unauthorised to Australia by boat to seek asylum played a key role in marginalise the issue during the election campaign.

First, the Australian government's adoption of a heightened deterrence paradigm towards asylum seekers arriving unauthorised in Australian waters by boat since August 2012 — and the subsequent implementation of OSB under the previous Abbott government (2013-15) — had seen the intensification of a politics of border security and practices of border securitisation and militarisation (Grewcock 2014). This paradigm entailed the turning back of boats carrying asylum seekers to source countries such as Vietnam or transit countries like Indonesia, increasing the capacity of the two offshore Regional Processing Centres (RPCs) in Papua New Guinea and Nauru, and reintroducing Temporary Protection Visas (TPVs) for certain refugees in Australia in the period leading up to the election. Moreover, in framing the phenomenon of people travelling to Australia by boat to seek asylum as a 'national emergency' and inaccurately deeming them 'illegal maritime arrivals' since 2014, such policies have further contributed towards the perception that refugees and asylum seekers should be seen as a potential threat to the 'security' of the Australian nation-state (Glendenning 2015). Praising the successes of OSB in 'regaining control over Australia's borders' would be central to the Coalition's campaigning on refugee issues during the election, allowing the Coalition to repeatedly invoke the threat of a future crisis while also defending their current policies and track record.

Since assuming government in 2013, the Coalition had sought to use refugee policy to make the ALP look weak and divided, despite supporting Labor's reintroduction of a model of regional offshore detention and 
processing in August 2012. In particular, Tony Abbott's adoption of the practice of turning back boats carrying asylum seekers en route to Australia remained a controversial policy in the early years of his government, not least because of Indonesia's vocal opposition to it. When Bill Shorten took over as Opposition Leader in October 2013, he actively sought to 'neutralise' the issue. This included successfully urging the party at the ALP national conference in July 2015 to endorse the Coalition's practice of turning back asylum seeker boats. As a result, much of the ALP's rhetoric in the lead-up to the 2016 election and during the campaign increasingly echoed that of the Coalition. For example, when challenged in relation to divisions within his parliamentary party on refugee policy during the campaign, Shorten reiterated Labor's support for both the policy of boat turn backs and offshore processing and declared that if elected the ALP would not 'put the people smugglers back in business' (Massola 2016).

The militarised approach for dealing with people seeking asylum adopted under OSB was accompanied by heightened secrecy around the implementation and effects of refugee policies by early 2016. Key legislative reforms, such as the adoption of the Australian Border Force Act 2015 (Cth), which was passed with bipartisan support but was opposed by the Greens, rrestricted the ability of certain professionals working in Australia's immigration detention regime to lawfully voice their concerns about the effects of Australia's refugee policies on people subject to the regime or to criticise the policies themselves. Indeed, these legislative changes drew sharp criticism from legal experts and human rights advocates for their suppression of whistleblowers. Under the then Act, contracted workers like doctors, teachers or other personnel in RPCs faced up to two years in prison for speaking publicly about the conditions or treatment of asylum seekers (Fleay 2015). ${ }^{2}$ Despite this alarming lack of transparency and silencing of professionals, there was still a number of exposés, in the form of testimony from whistleblowers or official documents obtained under freedom of information, in the lead-up to the 2016 election.

2 Subsequent to the 2016 election, the Secretary of the Department of Immigration and Border Protection (DIBP) amended a legislative instrument in September 2016 ahead of a High Court challenge to exempt 'health practitioners' from the definition of 'Immigration and Border Protection workers' under the Australian Border Force Act 2015 (Cth). See also DIBP, Determination of Immigration and Border Protection Workers-Amendment No. 1, 30 September 2016. Further significant legislative changes to the Act passed both Houses of Parliament in October 2017. 
Second, the lead-up to the election saw mounting evidence of the worsening treatment of people seeking asylum or found to be refugees in Australian-run onshore and offshore immigration detention centres, and in the region more generally. Reports emerged of negligence and abuse by contractors operating within the RPCs and of the high levels of self-harm among refugees and asylum seekers. For instance, in January 2016, internal Department of Immigration and Border Protection (DIBP) documents obtained under freedom of information showed that self-harm within both the onshore and offshore immigration detention centres had reached 'epidemic levels' (Koziol and Hasham 2016). A few months later in April 2016, the ABC's Four Corners program reported that senior doctors with experience of working in immigration detention were speaking out to highlight the 'dangerously inadequate' medical care in the Manus Island RPC (Thompson and Harley 2016). In response to such criticisms, the Australian government simply deflected its responsibility by repeatedly claiming that the Manus Island and Nauru RPCs were managed by the governments of PNG and Nauru respectively, under local laws, albeit with Australian support. Further media stories kept the issue of Australia's treatment of refugees and asylum seekers in the national spotlight, including evidence that the Royal Australian Navy had paid people smugglers to return asylum seekers to Indonesia. Regionally, in the years leading up to the 2016 election, Australian taxpayer-funded immigration detention centres across the Indonesian archipelago had also became desperately overcrowded and unhygienic, with claims that detained asylum seekers were being beaten and tortured (Missbach and Sinanu 2013).

Meanwhile, the Australian government adopted the dual tactics of pressuring people held in the Nauru or Manus Island RPCs to either return to their country of nationality or participate in third-country resettlement schemes. In September 2014, Australia signed a Memorandum of Understanding with Cambodia that enabled people found to be refugees in the Nauru RPC to voluntarily resettle in Cambodia on a permanent basis. The UNHCR criticised the $\$ 55$ million arrangement, labelling it 'a worrying departure from international norms' and asserting that 'it's crucial that countries do not shift their refugee responsibilities elsewhere' (UNHCR 2014). By 2016, it was clear that this arrangement proved to be 'a failure', with only five people opting to participate in the resettlement scheme, all but one of whom would eventually opt to 'voluntarily' return to their home countries (Murdoch and Koziol 2016). 
In Australia, many asylum seekers and refugees faced an increasingly precarious existence, largely because of the increasingly punitive government measures to limit people's rights to work and to family reunification (Fleay and Hartley 2016). The reintroduction of TPVs and Safe Haven Enterprise Visas (SHEVs) in December 2014 as the only visas available to people considered part of the so-called Asylum Legacy Caseload-a collective term for the approximately 30,000 people who arrived by boat between 2012 and 2014 and who were at the time yet to have their refugee claims processed and living in Australia on Bridging Visas-meant that any person who was subsequently found to be a refugee, but who had arrived in Australia unauthorised by boat, was unable to sponsor family members to join them in Australia (Crock and Bones 2015). Moreover, the Abbott government's adoption in December 2013 of a Code of Behaviour meant that asylum seekers living in the Australian community were subject to additional surveillance and the possibility of severe punishment for minor infractions (Methven and Vogl 2015).

Third, in the lead-up to the election, Australia faced increased domestic and international scrutiny of OSB and its offshore detention and processing arrangements, including through judicial challenges. Several reports from UN agencies found that Australia's policies constituted breaches of international laws, including the prohibition on subjecting people to torture, inhuman and degrading treatment (United Nations Human Rights Council 2014). For example, the riots in the Manus Island RPC in February 2014 had spurred the UN High Commissioner for Human Rights, Ravina Shamdasani, to criticise Australia and urge the Australian government to change its offshore detention and processing policy, or at the very least take 'steps to investigate, redress and punish human rights abuses by third parties' (quoted in Cumming-Bruce 2014). Domestic inquiries also called for policy change, with the Australian Human Rights Commission's (AHRC) inquiry into children in detention tabled in Parliament in February 2015, asserting that the 'mandatory and prolonged detention of children was a clear violation of international law', and issuing a recommendation to end to the mandatory detention of children and their families (AHRC 2014). The recommendations of both the UNHCR and the AHRC fell on deaf ears. Then prime minister Abbott instead defiantly responded to the Special Rapporteur's report by declaring that Australians were 'sick of being lectured to by the United 
Nations' (quoted in Cox 2015), and launched an all-out personal attack on the AHRC President Gillian Triggs, accusing her of publishing a 'stitch up' and publicly calling for her resignation.

A significant challenge to Australia's deterrence regime came in the leadup to the 2016 election in the form of a legal case within Papua New Guinea's (PNG) legal system. On 26 April 2016, the PNG Supreme Court, the highest judicial body in PNG, decided that the detention of asylum seekers in the Manus Island RPC was illegal as it breached the right to freedom of movement under the PNG Constitution. The Court thus ordered both the PNG and Australian governments to take 'all steps necessary' to end the illegal detention of the approximately 850 people in the Manus Island RPC (Namah v Pato [2016] SCA 84 of 2013 (PNG)). While the PNG decision provided an opportunity for the Coalition government to end the much-criticised and harmful policy of offshore detention and processing, the government staunchly refused to do so. Rather, Dutton vowed that the PNG decision would not change Australia's policies and that no one from the Manus Island RPC would be resettled in Australia (Tlozek and Anderson 2016). The government also again rejected an offer from New Zealand to permanently resettle a portion of the refugees, thus offering little alternative for resolving their legal obligations under PNG and international law and prolonging the suffering and uncertainty for the people interned on Manus Island.

Finally, the period leading up to the 2016 election saw the emergence of revitalised transnational activism from both within Australia's RPCs and the Australian community. Refugees and asylum seekers held continuous protests within both the Nauru and Manus Island RPCs as a way of highlighting the conditions of their incarceration and demanding proper pathways to permanent protection. In the middle of the election campaign in June 2016, the protests within the Nauru RPC passed 100 consecutive days. The photos and videos of these protests were shared by concerned Australians on social media and covered by some mainstream media outlets (Michael 2016).

At the same time, a mass social media campaign emerged in Australia during February 2016 under the slogan of \#LetThemStay, following a failed High Court challenge to halt the deportation of a pregnant Bangladeshi woman back to the Nauru RPC. This High Court decision meant that 267 asylum seekers and refugees who had been transferred from a RPC to Australia for medical treatment could be legally deported 
back to a RPC (see Plaintiff M68/2015 v Minister for Immigration and Border Protection (2016) 257 CLR 42). In response to such activism and community concern, Victorian Labor Premier Daniel Andrews, supported by then New South Wales Liberal Premier Mike Baird, prominently called for a 'better' solution to asylum-seeker policy than offshore detention and processing, and expressed a willingness to host refugees, particularly children and their families, so that they would not be returned to a RPC. The movement gained some further success, when medical staff at a Brisbane hospital refused to discharge 12-month-old 'baby Asha' in defiance of the government's position, with her family subsequently being settled in community detention in Australia. Further protests from professional, faith-based and community groups generated new political momentum for policy change, with over 100 churches offering sanctuary to those affected by the High Court decision. By April 2016, approximately half of the 267 asylum seekers at the centre of the Let Them Stay protests had been granted Bridging Visas that allowed them to remain in community detention in Australia (Oriti 2016). These protests gave increased national prominence to both the harmful effects of the current deterrence regime on people seeking asylum and articulated increasingly vocal calls for reform from within and beyond the refugee sector, and from the affected refugees and asylum seekers themselves.

\section{The election campaign}

Despite the confluence of circumstances that could have prompted a more prominent place for the issue of Australia's refugee policies in the 2016 federal election campaign, there instead appeared to be a peculiar shift away from the two major political parties foregrounding this issue. As noted previously, this was primarily because of the increasingly bipartisan support for the three key pillars of Australia's increasingly draconian deterrenceoriented model regarding asylum seekers in Australia. These pillars are the mandatory detention of people seeking asylum, the implementation of offshore processing and the practice of turning back asylum seeker boats en route to Australia. Nonetheless, in remaining more of an undercurrent in the election campaign, we argue that the issue of Australia's refugee policies did still appear at discrete moments during the campaign. As we discuss below, these moments involved contests around the 'appropriate' numbers of people to be admitted under Australia's 'offshore' humanitarian program; attempts to emphasise internal party divisions and instability 
within Labor; and, finally, appeals to maintaining the 'integrity' and control of the 'Australian border' - an end that has increasingly been infused with a rhetoric of instrumental humanitarianism that purports to be concerned with 'saving lives at sea'.

By and large, the increasing bipartisan support for a deterrence paradigm toward people attempting to seek asylum in Australia in recent years has meant that the main difference between the Coalition and Labor policies during the election campaign was in relation to the offshore resettlement component of Australia's humanitarian program. Here, the difference between the major parties appeared to be a contest over the number of people to be admitted under the offshore resettlement program and how to rhetorically frame this program. In their election campaign material, the Coalition's policy on refugees and asylum seekers appeared under the heading 'Protecting our Borders', and promised to maintain Australia's current annual humanitarian intake of 13,750 people, rising to 18,750 people in 2018-19. This number did not include the Abbott government's announcement in September 2015 that it would accept a one-off intake of 12,000 refugees displaced by the Syrian and Iraq conflicts. In contrast, Labor titled their policy 'A Humane and Compassionate Approach to Asylum Seekers', and pledged to eventually double the number of people resettled in Australia under the offshore resettlement program, amounting to an increased annual intake of 27,000 people by 2025 . Labor also committed to abolishing the use of TPVs that had been reintroduced under the Abbott government in December 2014. The Greens, as a third force in Australian politics, positioned themselves as a direct alternative to the Coalition and Labor's bipartisan deterrence paradigm, and strongly advocated for a rights-based approach of the processing of asylum seekers and refugees in Australia. Entitled 'A Better Way', the Greens' policy promised an increase of Australia's annual offshore humanitarian intake to 50,000 people. They also proposed adopting a new Skilled Refugee Visa program for 10,000 people, a measure that had long been called for by the Refugee Council of Australia (RCA) (see Table 26.1).

Interestingly, there was an implicit acknowledgement across all three of the major parties' policies that it is desirable to increase the number of places available annually in Australia's offshore humanitarian resettlement program over time, although neither the Coalition nor Labor advanced an explicit argument as to the basis of this decision. On a more fundamental level, the contests over these figures reveal an underlying dynamic of what Ghassan Hage has termed 'numerological racism' (2014: 233). For Hage, 
this denotes a racism of numbers in which discussing the admission of non-citizens to Australia 'always comes with the category of "too many"; that is, a sense that Australia currently takes or could take 'too many' refugees to the detriment of the national collective, and that the task for the Australian government is to find the appropriate numerical intake. Writing in the context of Pauline Hanson's anti-Asian racism in the late 1990s, Hage (1998: 186-89) suggested that such sentiments rely upon a 'fantasy of domination' in which the white sovereign decision-maker has the primary responsibility of controlling how many people deemed to be the 'Other' are to be admitted into the Australian nation, thus seeking to either restore or maintain a 'proper' balance to multicultural diversity. For Hage, such a dynamic reveals the insecure and anxious nature of Australian nationalism and the foundational norms underpinning practices of Australian multiculturalism (see also Hage 2003).

Table 26.1. Overview of major party refugee policies

\begin{tabular}{|c|c|c|c|}
\hline & $\begin{array}{l}\text { Coalition } \\
\text { 'Protecting } \\
\text { our Borders' }\end{array}$ & $\begin{array}{l}\text { Labor } \\
\text { 'A Humane and Compassionate } \\
\text { Approach to Asylum Seekers' }\end{array}$ & $\begin{array}{l}\text { Greens } \\
\text { 'A Better Way' }\end{array}$ \\
\hline \multicolumn{4}{|c|}{ 'Offshore' resettlement program } \\
\hline $\begin{array}{l}\text { Proposed annual } \\
\text { intake }\end{array}$ & $\begin{array}{l}18,750 \\
\text { people in } \\
2018-19\end{array}$ & 27,000 people in 2025 & 50,000 in 2016 \\
\hline \multicolumn{4}{|c|}{$\begin{array}{l}\text { 'Onshore' program for people travelling unauthorised to Australia by boat } \\
\text { to seek asylum }\end{array}$} \\
\hline $\begin{array}{l}\text { Mandatory } \\
\text { detention of asylum } \\
\text { seekers }\end{array}$ & $\begin{array}{l}\text { Yes, } \\
\text { unlimited }\end{array}$ & Yes, unlimited & $\begin{array}{l}\text { Yes, for a } \\
\text { maximum of } \\
30 \text { days }\end{array}$ \\
\hline $\begin{array}{l}\text { Offshore processing } \\
\text { of boat arrivals }\end{array}$ & Yes & Yes & No \\
\hline $\begin{array}{l}\text { TPVs for people } \\
\text { already in Australia }\end{array}$ & $\begin{array}{l}\text { Support } \\
\text { TPVs }\end{array}$ & Abolish TPVs & Abolish TPVs \\
\hline Boat turn backs & Yes & Yes & No \\
\hline $\begin{array}{l}\text { Reform of offshore } \\
\text { processing }\end{array}$ & No change & $\begin{array}{l}\text { Expedite processing of claims } \\
\text { Allow media access to RPCs }\end{array}$ & Close RPCs \\
\hline $\begin{array}{l}\text { Children in } \\
\text { immigration } \\
\text { detention }\end{array}$ & No change & $\begin{array}{l}\text { Introduce an independent } \\
\text { child advocate } \\
\text { Mandatory reporting } \\
\text { of child abuse }\end{array}$ & $\begin{array}{l}\text { Initiate a Royal } \\
\text { Commission to } \\
\text { investigate }\end{array}$ \\
\hline
\end{tabular}

Source. Compiled by authors from the election campaign materials of the Coalition (Liberal Party of Australia (LPA) 2016a), Australian Labor Party (ALP 2016) and Greens (Australian Greens 2016). 
During the election campaign, the competing figures around Australia's offshore humanitarian resettlement program became the subject of controversy following the appearance of Minister Dutton on a Sky News program as a guest of conservative host Paul Murray. Responding to Murray's outrage at the Greens' proposal to increase the size of Australia's humanitarian program, Dutton stated that refugees admitted under Australia's offshore humanitarian resettlement program were prone to unemployment and thus contributed to the government's spending on social security. The minister's remarks played on a long-held public misconception that asylum seekers receive greater welfare payments than members of the overall population (Phillips 2015). It is worth quoting Dutton's remarks at length for their contradictory framing of refugees as at once dependent upon social security and also 'taking Australian jobs':

For many people, they won't be numerate or literate in their own language let alone English ... These people would be taking Australian jobs. There's no question about that. And for many of them that would be unemployed, they would languish in unemployment queues and on Medicare, and the rest of it. So there would be a huge cost (cited in Bourke 2016).

Yet, despite the seeming contradiction in Dutton's remarks, at the heart of his comment is a representation of refugees as 'extractive' beings: as taking things to which Dutton suggests refugees should not be properly entitled (see Figure 26.1).

Commentators were quick to note that Dutton's incendiary comments, in constructing refugees as both a financial burden on the Australian taxpayers as well as a threat to the livelihood of 'Australian workers', misconstrued official data that demonstrates a majority of refugees resettled in Australia are in fact literate in their own language, understand spoken English on arrival and bring a net benefit to the Australian community and economy in the long run (Maddison 2016; Voon and Higgins 2016). Yet, interestingly, both Dutton's remarks and the outraged reactions to them engaged in the same rationalist calculation in which the legitimacy of the presence of refugees and asylum seekers within Australia is framed as a question of the 'burden' or 'benefit' that they bring to the nation. As Danielle Every (2008) has argued, such rationalist calculations reflect a dialectic within liberal humanitarianism that oscillates between foregrounding either of the opposing considerations of 'costs to self' or 'duty to others'. 
The following day, in defence of his comments and further labouring the idea of refugees as fiscal burdens, Dutton claimed that the Greens' policy would cost $\$ 7$ billion over four years while Labor's proposals would cost $\$ 2.3$ billion over the same period (Baxendale 2016). Prime Minister Malcolm Turnbull too, in coming to Dutton's defence as an 'outstanding immigration minister', claimed that Dutton's remarks merely reflected the fact that people resettled under Australia's offshore humanitarian program came from 'dreadful, devastated, war-torn regions of the world' (quoted in Keany and Anderson 2016). Opposition leader Shorten in turn seized on Dutton's remarks, labelled the Immigration Minister's comments 'xenophobic', 'offensive' and 'deeply divisive'. Claiming that the Coalition was seeking to 'undermine the migrant contribution to Australia because they don't want this election to be about the issues that matter to Australians', Shorten demanded that Dutton apologise for his remarks (quoted in Keany and Anderson 2016). While no apology was issued, it is telling that the main election campaign controversy pertaining to refugee policies was over a ministerial remark, rather than over the substance and effects of Australia's hardline deterrence policies.

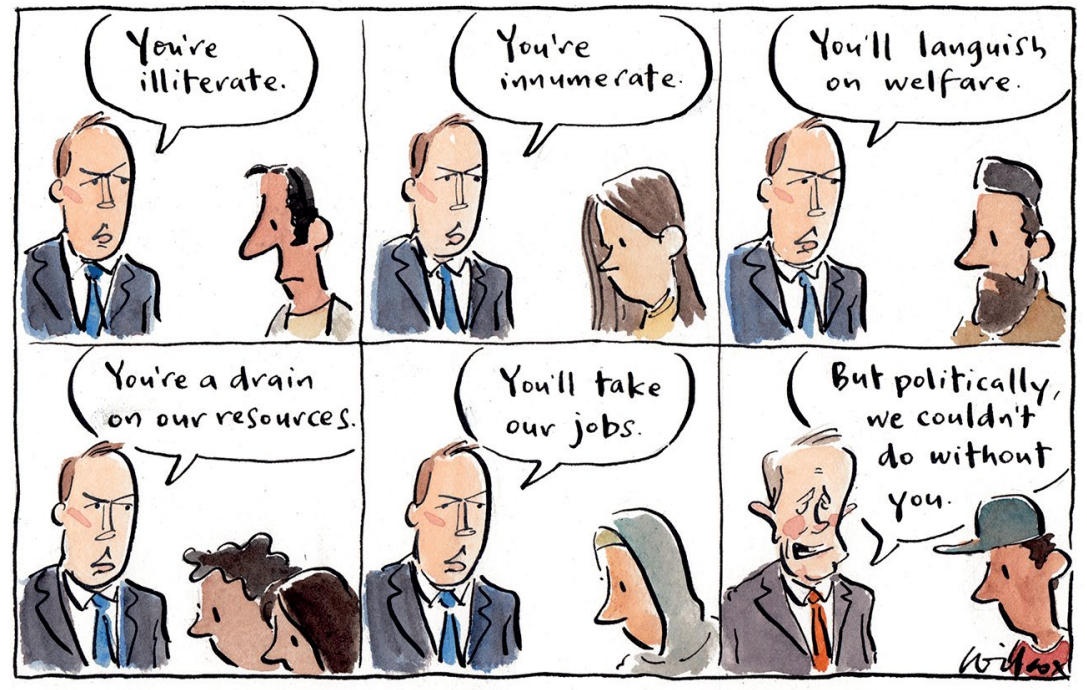

Figure 26.1. Refugees and the 2016 election

Source. Cathy Wilcox, 'Those invaluable refugees', Sydney Morning Herald, 23 May 2016. Reproduced with the permission of Cathy Wilcox. 
Throughout the campaign, the Coalition repeatedly used the question of refugee policy to suggest deep internal divisions within the Labor opposition. In his address to the federal campaign rally in late June 2016, Turnbull claimed that during their time in government, Labor had 'failed Australia at the border' by dismantling Howard-era refugee policies (LPA 2016b). Turnbull warned that the electorate could not risk a return to Labor given that 50 Labor candidates, Members of Parliament (MPs) and Senators allegedly did not currently support the government's deterrence model towards people arriving unauthorised by boat to seek asylum. To bolster this claim, the Liberal Party hosted an online website with a collage of images and quotes from Labor politicians and candidates who had come out in support of the \#Let ThemStay campaign or who had opposed the ALP adoption of a policy of 'boat turn backs' (Whatlaborreallythinks 2016). Rather than embracing the fact that there existed a diversity of views within his party, Shorten responded by framing the issue of dissent as one that had disappeared after the Labor Conference in 2015, insisting that the ALP now had the same deterrence policy as the Coalition. Yet such a proposition occluded the ongoing contestation about these policies within both the ALP and, to a lesser extent, the Coalition. This was evident, for example, in a minor controversy that occurred in the early weeks of the campaign, where Labor's candidate for the seat of Melbourne, Sophie Ismail, publicly stated that she had grave concerns about the policies of offshore processing and turning back asylum seeker boats en route to Australia. It is unclear how much traction the Liberal website, whatlaborreallythinks, actually received. What is clear is the government's perception that it could still make refugee policy into a partisan issue, despite Shorten's best efforts to neutralise it, and that years of positioning the Coalition as tough on the issue of 'border protection' had seemingly shaped voter judgement about the parties. For example, a poll conducted by Essential Vision in late May 2016 found that only 28 per cent of poll respondents believed Labor would keep the Coalition's policy on asylum seekers arriving by boat (Essential Vision 2016).

Finally, the election campaign saw the issue of refugee policies largely framed within the context of 'border security', with both Turnbull and Shorten using their respective refugee policies to present themselves as 'strong' leaders committed to 'protecting' Australia's borders. This was most apparent early in the Coalition's campaign when Turnbull visited an Australian Border Force (ABF) vessel docked in Darwin on 17 May 2016. Standing in front of the ACV Cape Jervis, Turnbull declared that 
the 'protection of Australia's borders is a political issue'. Praising the professionalism of the ABF, Turnbull appealed to his government's track record and commitment in 'keeping our borders secure'. He added that:

There are currently 1,400 people in Indonesia right now who came to Indonesia during the period of the Labor government in the hope that they would be able to get on a people smuggler's boat and come to Australia. And they know that they can't get through because of the commitment of my government; my government's determination to stop the boats and turn them back when we intercept them at sea. And that's why there's been no more boats. That's why it's been over 600 days without any unauthorised arrivals (quoted in Koziol 2016).

Dutton promoted this conflation between border protection, national security and asylum-seeker policies in a last-minute effort to gain voter confidence. The day before the federal election, Dutton explicitly linked the unauthorised arrival of asylum seekers in states with the occurrence of terrorist acts, suggesting that the political violence in parts of Europe was the product of countries having 'lost control' of their borders. On the Labor side, Shorten sought to regain ground in the area of national security following claims of criminal syndicates and people smugglers rorting the Australian visa system in late June. However, these allegations, coming late in the election campaign, failed to generate much political controversy or inflict political damage on the sitting Coalition government.

A further example of the Coalition's willingness to politicise the issue of refugee policy came a little over a week out from the election, when the Turnbull government announced that it had rerouted a boat with 21 asylum seekers en route to Australia back to Vietnam. The Coalition attempted to use this as further evidence that 'the challenge of people smuggling is greater than it has ever been' and that Labor's policy of abolishing TPVs would send an 'invitation' to people smugglers to resume their trade in human lives (ABC Radio 2016). Labor, given their support of the boat turn-back policy, was left with little room for criticising the actual action, opting to instead question the delayed timing of the announcement given that the boat had been intercepted and returned earlier in June. Shorten responded by labelling border security the Coalition's 'break-glass issue'. This instance revealingly demonstrated the Coalition's readiness to disregard their prohibition on discussing 'on water operational matters' for the sake of political expediency. 
Tellingly, the bipartisan deterrence paradigm was increasingly infused with a humanitarian rhetoric throughout the 2016 election campaign. For example, during his appearance on the national $Q \& A$ program on $\mathrm{ABC}$ television, Turnbull framed the issue of the indefinite detention of people in RPCs as one of a resolute determination to combat people being exploited by people smugglers, and to ensure that no person drowns at sea while attempting to reach Australia by boat (Boochani 2016). Turnbull's comments were in response to a question asked via video from the Manus Island RPC by Behrouz Boochani, a Kurdish Iranian journalist who has spent more than three years in PNG. Turnbull remarked:

We have learnt the tragic truth that when the very strict and clear border protection policies of the Howard government were ... undone by Kevin Rudd, we had 50,000 unlawful arrivals, we had 1,200 deaths at sea of which we know. It was a catastrophe. Now we have been able to secure the security on the border. The people smugglers are out of business. They would love to get back into business. They are itching to get back into business ... We have had no unauthorised arrivals ... for well over 660 days ... It is a tough policy, I grant you that (quoted in Boochani 2016).

Turnbull's response here advances a form of instrumental humanitarianism that posits that denying people arriving without authorisation access to asylum and incarcerating others is not only good for Australia as a nation, but also serves as a humane and justified means of preventing loss of life and human exploitation. Yet as Maria O'Sullivan (2016) has argued, Australia's policies that prioritise formal resettlement schemes while preventing and penalising anyone who seeks asylum outside the parameters of such schemes is ethically unacceptable. For O'Sullivan, such an approach risks denying individual agency to refugees to decide their mode of accessing asylum and comes at an 'extremely high cost to the individual rights of other persons who receive punitive treatment for not using a planned process' (2016: 256). This form of instrumental humanitarianism then bolsters rather than displaces the securitisation of migration and seeks to delegitimise the asylum rights of people travelling to Australia without authorisation.

Commentators dispute what is driving the bipartisan policy towards refugees. Polls released during the 2016 election campaign suggest that most Australians do not fully support the bipartisan hardline approach towards people seeking asylum. For example, a poll surveying 1,400 people commissioned by the Australia Institute (2016) found that 63 per cent of respondents opposed the bipartisan policy that did not allow refugees 
who have travelled without authorisation by boat to settle in Australia. A further poll for the Lowy Institute (2016) claimed that 57 per cent and 58 per cent of respondents regarded 'immigration' and 'refugees and asylum seekers' as very important issues for Australia, respectively; however, such statistics fail to reveal the particular values placed upon the issue. The Australian Election Survey (AES) has shown declining support for the practice of turning back asylum seeker boats over the last 15 years, with 62 per cent of respondents supporting the practice in 2001 compared to 49 per cent in 2013 (McAllister and Cameron 2014). In contrast, the 2016 Lowy Institute survey showed that 63 per cent of Australians appear to support the controversial policy of asylum seeker boat 'turn backs'. It also found, however, that 73 per cent of those surveyed agreed that immigration has a positive impact on the Australian economy (Lowy Institute 2016). These mixed poll results support the findings of Murray Goot and Ian Watson (2011), who observed that the outcome of polls concerning immigration often depended upon the particular way in which the question was asked. For example, survey polls reporting high levels of opposition to refugee and migrants appeared to encourage such responses through the particular wording of the question.

Despite both the Coalition and Labor's overall reluctance to elevate the issue of refugee policy to the status of a major party platform or to a key election slogan, it did receive notable coverage in the mainstream media. The Murdoch-owned News Corp press appeared particularly willing to cover, in an incendiary manner, the issue of people arriving unauthorised to Australia by boat. For example, during the second week of the campaign, News Corp's Herald Sun (Australia's highest circulating newspaper) ran the headline 'Shorten Holed on Boats', with the subtitle of 'Seven Labor Candidates at Odds with Opposition Leader on Asylum Seekers' (Harris 2016). As discussed in Andrea Carson and Brian McNair (Chapter 19, this volume), data monitoring of print and online media during the election campaign indicates that asylum seeker issues repeatedly appeared among the top five issues discussed within the mainstream media in a given week. This prominence is also reflected in analyses of alternative media and social media platforms (see Chen, Chapter 20, this volume). 


\section{Legacies of the 2016 election}

Undoubtedly, the bipartisan nature of the three main tenets that make up Australia's current policies towards people seeking asylum-mandatory detention, regional processing and boat turn backs - meant that there was little to distinguish the campaign policies of Labor and the Coalition. When Labor was prepared to concede that differences existed between the two parties' policies, it was differences in procedure rather than substance. For example, the ALP promised to expedite the processing of claims in RPCs and to facilitate increased transparency by pushing for journalists to have access to these centres.

One legacy of the election campaign has been the success of new electoral tactics adopted by several prominent refugee and human rights advocacy organisations. While many NGOs appeared reluctant to push directly for a discussion of Australia's refugee policy during the election campaign for fear of a 'race to the bottom' between both major parties, some organisations still encouraged voters to consider the issue of refugee policy at the ballot. The RCA, for example, released a briefing paper that compared the policies and measures of the two major political parties and the Greens in the hope of promoting national dialogue and voter awareness of the issue (RCA 2016). The most successful of these campaigns was that coordinated by the non-party affiliated progressive organisation GetUp!, who adopted the strategy of targeting seats held by the conservative right wing of the Liberal Party on the basis that such politicians were 'standing in the way of progress' on key issues such as climate action (see Vromen, Chapter 18, this volume). Most notably, this strategy included targeting Dutton in his Brisbane electorate of Dickson, a seat held by Dutton for the Liberal-National Party (LNP) since 2001. After the 2013 election, Dutton had a comfortable 6.7 per cent margin. Following the 2016 election, this margin was reduced to 3.2 per cent, resulting in LNP fears that Dutton may lose his seat in what eventually amounted to a 5.12 per cent swing against him on a two-party preferred count (more than double the national average swing against the LNP). Dutton himself cited GetUp!'s campaign as a reason why he had had a 'very tough campaign' marked by continuous protests. Indeed, the GetUp! campaign, titled 'Time to Ditch Dutton', had seen over 28,291 calls made to voters in Dickson and 294 volunteers on the ground in the electorate engaging in a range of activities from door knocking in the 
weeks leading up to the election to handing out leaflets on election day. ${ }^{3}$ This mobilisation constituted one of the largest campaigns run by GetUp! in any of the electorates that they targeted during the election campaign (GetUp! 2016).

A second legacy of the 2016 election has been the return of Pauline Hanson's One Nation (PHON) to the Australian Parliament on an explicitly anti-immigration platform. The party managed to claim four Senate seats, most notably two in QLD, and is set to be a decisive force in the current Australian Parliament. In the context of refugee policy, PHON ran on an overtly nationalist platform of endorsing the system of TPVs for refugees, abolishing the bipartisan policy of multiculturalism that has been in place in Australia since the 1970s and placing a ban on Muslim immigration to Australia, including banning Muslim refugees. This latter policy echoed the open xenophobia and Islamophobia of right-wing populist movements elsewhere in the USA and Europe, most notably seen in Donald Trump's presidential election campaign and the current policies of his administration.

The return of Pauline Hanson's One Nation to the Australian Parliament is certainly troubling for the future direction of Australia's refugee policies. However, the policies advocated by PHON need to be seen as consistent with, rather than a challenge to, the key principles of deterrence, exclusion and incarceration that have come to underpin Australia's refugee policies since the early 1990s, further coupled with recent articulations of Islamophobia in western democracies. Although it may be easy to attribute the strong return of One Nation to rising xenophobia in some sections of the Australian public, other factors have had a considerable influence on the election outcome. Tim Colebatch, for example, has argued that the lower threshold for Senate seat quotas in a double-dissolution election as well as the senate voting changes were responsible for the seats gained by PHON (Colebatch 2016).

\section{Conclusion}

The 2016 election may not have been decided on the issue of refugee policy, but this issue is almost certainly set to remain prominent on the Australian political agenda. This is particularly the case as Australia's

3 These figures have been sourced from an email with GetUp! (on file with authors). 
hardline bipartisan approach comes under increased scrutiny and pressure from a range of actors including international organisations like the UNHCR, domestic judicial bodies such as the High Court, networks of refugee advocates and activists, as well as, most importantly, the people who have been the subject of these changing policies, either on Manus Island and Nauru or living on the Australia mainland. In the aftermath of the 2016 election, Australia's refugee policies again became the subject of sustained national and international attention because of the 'oneoff Australia-US refugee resettlement deal signed between the Turnbull government and the departing Obama Administration in November 2016. Under the terms of the agreement, the US agreed to permanently resettle in the US up to 1,250 refugees currently on Nauru or Manus Island, with priority given to women, children and families. In return, Australia agreed to resettle refugees from Central America currently being held in Costa Rica. Yet, despite US President Trump in February 2017 publicly questioning the deal and labelling it 'dumb', the arrangement has remained in place. US immigration officials interviewed people in RPCs in late 2016 and the first group of 52 refugees arrived in the US for resettlement in September 2017 (Anderson and Belot 2016; Tlozek 2017). While this resettlement scheme will provide a durable solution for a small number of people to start new lives in a safe country, its ability to provide a means of redressing the policy failures and human costs of Australia's offshore processing approach remains doubtful.

The 2016 election demonstrates that the two major parties appear unwilling to depart from their bipartisan support of the three key tenets of Australia's deterrence regime towards people travelling to Australia to seek protection-namely, the regional detention and processing deterrence model, the turning back of asylum seeker boats and the mandatory detention of people seeking asylum in Australia. Moreover, key moments during the 2016 election revealed the disturbing pervasiveness of the discursive construction of refugees and asylum seekers as a threat to Australia's security and identity. Nevertheless, the harmful effects of Australia's policies towards refugees will continue to pose an ongoing political and ethical impetus for a change to this troubling bipartisanship. It may well be that the issue of Australia's refugee policy will assume an increased visibility at the next federal election if this bipartisanship can be shifted but, in 2016, it did not. 


\section{References}

ABC Radio. 2016. 'Coalition warns Labor will encourage people smugglers if it wins election'. PM. Available at: www.abc.net.au/pm/ content/2016/s4487132.htm

Anderson, Stephanie and Henry Belot. 2016. 'Donald Trump slams "dumb" refugee deal with Australia after "worst" phone call'. $A B C$ News, 3 February. Available at: www.abc.net.au/news/2017-0202/trump-slams-dumb-refugee-deal/8235820

Australia Institute. 2016. 'Asylum seeker policy - Polling brief'. June. Available at: www.tai.org.au/sites/defualt/files/Polling\%20Brief\%20\%20May\%202016\%20-\%20Asylum\%20Seeker\%20Policy.pdf

Australian Greens. 2016. 'Immigration and refugees'. Available at: greens.org.au/policies/immigration-refugees

Australian Human Rights Commission (AHRC). 2014. The Forgotten Children: National Inquiry into Children in Immigration Detention. Available at: www.humanrights.gov.au/sites/default/files/document/ publication/forgotten_children_2014.pdf

Australian Labor Party (ALP). 2016. 'A humane and compassionate approach to asylum seekers'. Available at: www.alp.org.au/asylumseekers

Baxendale, Rachel. 2016. 'Federal election 2016: Greens refugee policy to cost \$7bn, Dutton's office says'. Australian, 18 May. Available at: www.theaustralian.com.au/federal-election-2016/federal-election2016-greens-refugee-policy-to-cost-7bn-duttons-office-says/news-stor y/8f45775d4a5b3efc8d77ec62a5e77f75

Boochani, Behrouz. 2016. 'Malcolm Turnbull, why didn't you answer my question on Q\&A about Manus Island?' Guardian, 21 June. Available at: www.theguardian.com/commentisfree/2016/jun/21/ malcolm-turnbull-why-didnt-you-answer-my-question-on-qa-aboutmanus-island 
Bourke, Latika. 2016. 'Peter Dutton says "illiterate and innumerate" refugees would take Australian jobs'. Sydney Morning Herald, 18 May. Available at: www.smh.com.au/federal-politics/federal-election-2016/ peter-dutton-says-illiterate-and-innumerate-refugees-would-takeaustralian-jobs-20160517-goxhj1.html

Colebatch, Tim. 2016. 'Fear puts One Nation back where it counts'. Inside Story, 4 August. Available at: insidestory.org.au/fear-puts-onenation-back-where-it-counts

Cox, Lisa. 2015. 'Tony Abbott: Australians "sick of being lectured to" by United Nations, after report finds anti-torture breach'. Sydney Morning Herald, 10 March. Available at: www.smh.com.au/federal-politics/ political-news/tony-abbott-australians-sick-of-being-lectured-toby-united-nations-after-report-finds-antitorture-breach-20150309$13 z 3 j 0 . h t m l$

Crock, Mary and Kate Bones. 2015. 'Australian exceptionalism: Temporary protection and the rights of refugees'. Melbourne Journal of International Law 16(2): 522-49.

Cumming-Bruce, Nick. 2014. 'U.N. Office criticizes Australia detention policies'. International New York Times, 21 February. Available at: www. nytimes.com/2014/02/22/world/asia/un-office-criticizes-australiadetention-policies.html

Essential Vision. 2016. 'Policy on asylum seekers'. Available at: www. essentialvision.com.au/policy-on-asylum-seekers

Every, Danielle. 2008. 'A reasonable, practical and moderate humanitarianism: The co-option of humanitarianism in the Australian asylum seeker debates'. Journal of Refugee Studies 21(2): 210-29. doi. org $/ 10.1093 /$ jrs/fen 013

Fleay, Caroline. 2015. 'The limitations of monitoring immigration detention in Australia'. Australian Journal of Human Rights 21(1): $21-46$.

Fleay, Caroline and Lisa Hartley. 2016. "I feel like a beggar": Asylum seekers living in the Australian community without the right to work'. Journal of International Migration and Integration 17(4): 1031-48. doi.org/10.1007/s12134-015-0453-x 
Fleay, Caroline and Sue Hoffman. 2014. 'Despair as a governing strategy: Australia and the offshore processing of asylum-seekers on Nauru'. Refugee Survey Quarterly 33(2): 1-19. doi.org/10.1093/rsq/hdu004

GetUp!. 2016. 'Election 2016: People powered impact'. Get $U_{p}$ !. Available at: d68ej2dhhub09.cloudfront.net/1873-Getup-ElectionReport-MP-2016.pdf

Glendenning, Phil. 2015. 'Asylum seekers, refugees and human dignity'. Social Alternatives 34(1): 27-33.

Goot, Murray and Ian Watson. 2011. Population, Immigration and Asylum Seekers: Patterns in Australian Public Opinion. Canberra: Australian Parliamentary Library Pre-Election Policy Unit.

Grewcock, Michael. 2014. 'Australian border policing: regional "solutions" and neocolonialism'. Race \& Class 55(3): 71-78.

Hage, Ghassan. 1998. White Nation: Fantasies of White Supremacy in a Multicultural Society. Annandale: Pluto Press.

- 2003. Against Paranoid Nationalism: Searching for Hope in a Shrinking Society. Annandale: Pluto Press.

- 2014. 'Continuity and change in Australian Racism'. Journal of Intercultural Studies 35(3): 223-31. doi.org/10.1080/07256868.2 014.899948

Harris, Rob. 2016. 'Shorten holed on boats'. Herald Sun, 17 May, p. 1.

Hutchens, Peter. 2016. 'Peter Dutton says Coalition "a victim of its own success" in election campaign'. Guardian, 7 July. Available at: www.theguardian.com/australia-news/2016/jul/07/peter-dutton-sayscoalition-a-victim-of-its-own-success-in-election-campaign

Keany, Francis and Stephanie Anderson. 2016. 'Election 2016: Malcolm Turnbull backs "outstanding" Peter Dutton after refugee comments'. ABC News, 18 May. Available at: www.abc.net.au/news/2016-05-18/ dutton-warns-illiterate-refugees-will-take-aussie-jobs/7424198

Koziol, Michael. 2016. 'Election 2016: The logo you're not supposed to see with Malcolm Turnbull'. Sydney Morning Herald, 17 May. Available at: www.smh.com.au/federal-politics/federal-election-2016/ election-2016-the-logo-youre-not-supposed-to-see-with-malcolmturnbull-20160517-gowvje.html 
Koziol, Michael and Nicole Hasham. 2016. 'Self-harm in detention centres at epidemic levels, internal documents show'. Sydney Morning Herald, 16 January. Available at: www.smh.com.au/federal-politics/ political-news/selfharm-in-detention-centres-at-epidemic-levelsinternal-documents-show-20160115-gm74q3.html

Liberal Party of Australia (LPA). 2016a. 'Issue 09: Protection our borders'. Available at: www.liberal.org.au/our-plan/protecting-our-borders

2016b. 'Prime Minister's address to the 2016 Federal Campaign Rally'. 26 June. Available at: www.liberal.org.au/latest-news/2016/06/ 26/prime-ministers-address-2016-federal-campaign-rally

Lowy Institute. 2016. Poll 2016: 'Australian and the world'. Available at: www.lowyinstitute.org/publications/lowy-institute-poll-2016

Maddison, Sarah. 2016. 'Why "illiterate" jibe is an election dog whistle'. Election Watch, 20 May. Available at: pursuit.unimelb.edu.au/articles/ why-illiterate-jibe-is-an-election-dog-whistle

Massola, James. 2016. 'Election 2016: Labor's Melbourne candidate Sophie Ismail contradicts party asylum seeker policies'. Sydney Morning Herald, 9 May. Available at: www.smh.com.au/federal-politics/federalelection-2016/election-2016-labors-melbourne-candidate-sophieismail-contradicts-party-asylum-seeker-policies-20160508-gopj8l.html

McAllister, Ian and Sarah Cameron. 2014. 'Trends in Australian Political Opinion: Results from the Australian Election Study, 19872013'. Canberra: School of Politics and International Relations, The Australian National University.

Methven, Elyse and Anthea Vogl. 2015. 'We will decide who comes to this country, and how they behave: A critical reading of the asylum seeker code of behaviour'. Alternative Law Journal 40(3): 175-79.

Michael, Peter. 2016. 'Manus Island: Asylum seekers, locals left in limbo with closure of detention centre'. news.com.au, 21 May. Available at: www.news.com.au/national/politics/manus-island-asylum-seekerslocals-left-in-limbo-with-closure-of-detention-centre/news-story/fd1 e115d92b5e1dc17d5958654b4c21c 
Missbach, Antje and Frieda Sinanu. 2013. 'Life and death in immigration detention'. Inside Indonesia 113 (July-September 2013). Available at: www.insideindonesia.org/life-and-death-in-immigration-detention

Murdoch, Lindsay and Michael Koziol. 2016. 'Australia's Cambodia refugee resettlement plan "a failure". Sydney Morning Herald, 3 April. Available at: www.smh.com.au/world/australias-cambodia-refugeeresettlement-plan-a-failure-20160403-gnx3jv.html

Oriti, Thomas. 2016. 'Let Them Stay labelled a success, more than half of 267 asylum seekers in community detention'. ABC News, 2 April. Available at: www.abc.net.au/news/2016-04-02/let-themstay-labelled-success-asylum-seeker-community-detention/7294456

O'Sullivan, Maria. 2016. 'The ethics of resettlement: Australia and the Asia-Pacific region'. International Journal of Human Rights. 20(2): 241-63. doi.org/10.1080/13642987.2015.1103523

Phillips, Janet. 2015. Asylum seekers and Refugees: What are the Facts? Parliamentary Library Research Paper Series 2014-15. Canberra: Department of Parliamentary Services.

Refugee Council of Australia (RCA). 2016. '2016 Federal Election: Refugee Policies of Labor, Liberal-National Coalition and The Greens'. Available at: www.refugeecouncil.org.au/wp-content/uploads/2016/ 06/2016-FEDERAL-ELECTION-POLICIES.pdf

Thompson, Geoff and Wayne Harley. 2016. 'Bad Blood'. 4 Corners, 25 April. Available at: www.abc.net.au/4corners/stories/2016/04/25/ 4447627.htm

Tlozek, Eric. 2017. 'Manus Island: First refugees leave PNG for US under swap deal'. $A B C$ News, 26 September. Available at: www.abc.net. $\mathrm{au} /$ news/2017-09-26/22-refugees-leave-manus-island-for-us-swapdeal/8988424

Tlozek, Eric and Stephanie Anderson. 2016. 'PNG's Supreme Court rules detention of asylum seekers on Manus Island is illegal'. ABC News, 27 April. Available at: www.abc.net.au/news/2016-04-26/png-courtrules-asylum-seeker-detention-manus-island-illegal/7360078 
Turnbull, Malcolm. 2016. 'Prime Minister's address to the 2016 Federal Campaign Rally'. Speech: 26 June. Available at: www.malcolm turnbull.com.au/media/prime-ministers-address-to-the-2016-federalcampaign-rally

United Nations High Commissioner for Refugees (UNHCR). 2014. 'UNHCR statement on Australia-Cambodia agreement on refugee relocation'. 26 September. Available at: www.unhcr.org/news/ press/2014/9/542526db9/unhcr-statement-australia-cambodiaagreement-refugee-relocation.html

—. 2016. 'Trends in forced displacement in 2015'. Geneva: UNHCR.

United Nations Human Rights Council. 2014. 'Special Rapporteur on torture and other cruel, inhuman or degrading treatment or punishment'. Available at: www.ohchr.org/EN/Issues/Torture/ SRTorture/Pages/SRTortureIndex.aspx

Voon, Frances and Claire Higgins. 2016. 'Dutton's refugee claims are out of step with evidence and thinking at home and abroad'. The Conversation, 19 May. Available at: theconversation.com/duttonsrefugee-claims-are-out-of-step-with-evidence-and-thinking-at-homeand-abroad-59626

Whatlaborreallythinks. 2016. 'Labor on border protection: What they really think...'. Available at: www.whatlaborreallythinks.com.au/

\section{Legislation}

Australian Border Force Act 2015 (Cth).

Department of Immigration and Border Protection (DIBP), Determination of Immigration and Border Protection Workers-Amendment No. 1, 30 September 2016.

\section{Cases}

Namah v Pato [2016] SCA 84 of 2013 (PNG).

Plaintiff M68/2015 v Minister for Immigration and Border Protection (2016) 257 CLR 42. 
This text is taken from Double Disillusion: The 2016 Australian Federal Election, edited by Anika Gauja, Peter Chen, Jennifer Curtin and Juliet Pietsch, published 2018 by ANU Press, The Australian

National University, Canberra, Australia.

doi.org/10.22459/DD.04.2018.26 